\title{
Infant Mortality, AIDS
}

National Cancer Institute

\section{Source}

National Cancer Institute. Infant Mortality, AIDS. NCI Thesaurus. Code C19239.

infant death due to AIDS 